\title{
A case of pleural effusion caused by infection from Toxocara canis
}

\author{
Rosanna Qualizza ${ }^{1 *}$, Cristoforo Incorvaia', Policlinico Anna Maraschini ${ }^{2}$ \\ From 3rd WAO International Scientific Conference (WISC) 2014 \\ Rio de Janeiro, Brazil. 6-9 December 2014
}

\section{Background}

Toxocara canis is an intestinal nematode affecting dogs and cats which causes human infestation through the ingestion of embryonated eggs excreted in faeces. Once larvae have migrated to various tissues and organs, they can cause a wide array of clinical symptoms. We describe a case of pleural effusion caused by T. canis infection.

\section{Methods}

The patient was a 56-year old Caucasian woman suffering from rheumatoid arthritis since 1995. She was subsequently diagnosed with Sjoegren's syndrome and autoimmune thyroiditis. In 2009, the patient had a skin rash which disappeared after corticosteroid treatment. In January 2012 a routine chest X-ray detected a pleural effusion, that was treated by various cycles of antibiotics and corticosteroids without improvement. The patient was then referred to us because of a concomitant eosinophilia. She also had difficulty in breathing, and allergy was suspected as a possible cause. The patient underwent allergy tests, parasitological evaluation and a routine blood examination, including IgG antibodies to T. canis.

\section{Results}

Allergy tests were negative, while IgG antibodies to T. canis. were positive by both ELISA and Western Blotting. An anti-elminthic treatment was prescribed using mebendazole (one $100 \mathrm{mg}$ tablet b.i.d. for three days), repeated in subsequent cycles with a 1-month time interval. After the first cycle, a chest X-ray showed that the pleural effusion had improved. Complete recovery was shown after 4 months by X-ray and ecography, being associated to a negative serology result for T. canis and to resolution of eosinophilia.

${ }^{1}$ Istituti Clinici Di Perfezionamento, Italy

Full list of author information is available at the end of the article

\section{Conclusions}

T. canis. infection should be taken into account in cases of pleural effusion resistant to conventional treatment. The in vitro detection of $T$. canis-specific IgG antibodies leads to appropriate, effective anti-elminthic treatment.

\section{Consent}

Written informed consent was obtained from the patient for publication of this abstract and any accompanying images. A copy of the written consent is available for review by the Editor of this journal.

\section{Authors' details \\ ${ }^{1}$ Istituti Clinici Di Perfezionamento, Italy. ${ }^{2}$ Irccs Fondazione Ca' Granda Ospedale Maggiore, Italy.}

Published: 8 April 2015

doi:10.1186/1939-4551-8-S1-A131

Cite this article as: Qualizza et al:: A case of pleural effusion caused by infection from Toxocara canis. World Allergy Organization Journal 2015 8(Suppl 1):A131.
Submit your next manuscript to BioMed Central and take full advantage of:

- Convenient online submission

- Thorough peer review

- No space constraints or color figure charges

- Immediate publication on acceptance

- Inclusion in PubMed, CAS, Scopus and Google Scholar

- Research which is freely available for redistribution
( Biomed Central 